Primljen / Received: 13.12.2011.

Ispravljen / Corrected: 4.4.2012.

Prihvaćen / Accepted: 20.4.2012.

Dostupno online / Available online: 25.5.2012.

\section{Analysis of heat transfer design models based on EN1993-1-2}

Authors:

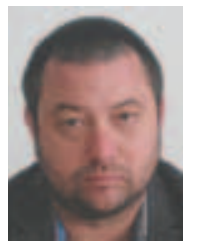

Prof. Ivica Boko, PhD. CE

University of Split

Faculty of Civil Engineering, Arch. and Geodesy ivica.boko@gradst.hr

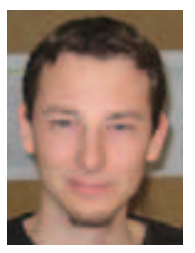

Neno Torić, B.Sc. CE University of Split

Faculty of Civil Engineering, Arch. and Geodesy neno.toric@gradst.hr

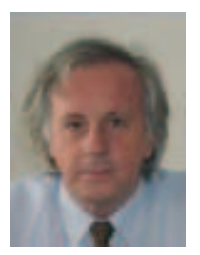

Prof. Bernardin Peroš, PhD. CE

University of Split

Faculty of Civil Engineering, Arch. and Geodesy bernardin.peros@gradst.hr
Ivica Boko, Neno Torić, Bernardin Peroš

Original scientific paper

\section{Analysis of heat transfer design models based on EN1993-1-2}

An overview of experimental research conducted in order to test basic design models relating to temperature increase in structures in case of fire action, as given in EN $1993-1-2$, is presented in the paper. The analysis was conducted for basic design models relating to temperature increase in protected and unprotected steel elements. Steel elements with protection in form of a fire-resistant coating are analyzed.

Key words:

heat transfer, fire-resistant coating, fire, thermal properties, steel, unprotected and protected element

\section{Ivica Boko, Neno Torić, Bernardin Peroš}

Izvorni znanstveni rad

\section{Analiza proračunskih modela provodenja topline iz EN1993-1-2}

U radu su opisana eksperimentalna istraživanja koja su provedena u svrhu testiranja osnovnih proračunskih modela iz EN 1993-1-2 za proračun povećanja temperatura u konstrukciji u slučaju djelovanja požara. Analiza je provedena za osnovne modele proračuna povećanja temperature u zaštićenim i nezaštićenim čeličnim elementima. Analizirani su čelični elementi sa zaštitom u obliku protupožarnog premaza.

\section{Ključne riječi:}

provodenje topline, protupožarni premaz, požar, toplinske karakteristike, čelik, nezaštićeni element, zaštićeni element

Ivica Boko, Neno Torić, Bernardin Peroš

Wissenschaftlicher Originalbeitrag

Analyse der Berechnungsmodelle der Wärmeleitfähigkeit nach EN1993-1-2

In der Arbeit sind experimentelle Forschungen, die zum Zwecke der Testierung grundlegender, in EN 1993-1-2 für die Berechnung der Temperaturerhöhung in einer Konstruktion im Falle einer Brandwirkung festgegebener Berechnungsmodelle dargestellt. Die Analyse wurde für Grundmodelle der Berechnung von Temperaturerhöhungen in geschützten und ungeschützten Stahlelementen durchgeführt. Es wurden Stahlelemente mit Schutz in Form eines Brandschutzanstriches analysiert.

Schlüsselwörter:

Wärmeleitfähigkeit, Brandschutzanstrich, Brand, Wärmecharakteristiken, Stahl, ungeschütztes und geschütztes Element 


\section{Introduction}

Heat transfer calculation represents the first step in the modelling of the behaviour of structures exposed to fire. The contemporary European norms for the calculations of steel structures - EN1993-1-2 [1] currently represent the basis for the engineering calculations of steel structures exposed to high temperatures due to fire. Two types of simple heat transfer models for calculation of temperatures inside the structure are given in EN1993-1-2. The models depend upon the type of protection of steel - unprotected internal steelwork and steelwork protected by fire insulation material. Such models are furthermore dependent upon a given number of critical parameters which are used for temperature calculations. Generally, these parameters are divided into four groups:

- Thermal parameters (thermal conductivity and specific heat capacity),

- Boundary condition parameters (convection and radiation transfer coefficient, configuration factor),

- Fire action parameters (hot gas temperature in the vicinity of steel element),

- Cross-section shape parameters (section and shadow factor).

The presented groups of parameters are most frequently determined by experiments, by direct or indirect experimental methods which have been developed, in the course of years, by various researchers. Consequently, the literature presents deviations of the results of certain parameters obtained by other researchers from those empirically determined in dependence with temperature by EN1993-1-2.

The objective of this study is to test the validity of simple calculation models according to EN1993-1-2 for the determination of the development of fire temperatures in protected and unprotected steel elements and to compare the results with conducted experimental research [2]. The study includes the measurements of the developed temperature on the element surface for various cases of temperature heating gradients of the analysed elements. The paper presents a new methodology for the calculation of temperature development in the steel elements protected by an intumescent coating since no specific guidelines for such a type of element protection have been given in EN1993-1-2.

\section{Previous studies}

This chapter presents experimental and theoretical investigations dealing with the heat characteristics of steel and calculation models for heat transfer used for the drafting of EN 1993-1-2.

\subsection{Thermal characteristics of steel}

The basic parameters which define the intensity of temperature developed in a steel element resulting from fire action are specific heat capacity and thermal conductivity of the material.
The thermal characteristics of steel presented in Eurocode 3 have been defined according to a report presented by Anderberg [3], which gives the results of the thermal and mechanical characteristics of steel available at the time, as well as on the basis of other publications $[4,5]$. The experimental investigations of the thermal characteristics of steel conducted so far $[6,7]$ have proved a satisfactory agreement of the experimental results with the empirical models of the coefficient of thermal conductivity given in Eurocode 3. The experimental results of the specific heat capacity obtained by various researchers are in accordance with the model from Eurocode 3 up to $700^{\circ} \mathrm{C}$, whereas greater deviations occur above the given temperature, especially in the area with a sudden rise in the value of heat capacity $\left(750^{\circ} \mathrm{C}\right)$ caused by the phase change in the material. Taking into consideration the mentioned facts, the previous experimental researches show low variations of the thermal characteristics of steel within the temperature range up to $700^{\circ} \mathrm{C}$ and satisfactory agreement of the experimental researches with the models presented in EN1993-1-2.

\subsection{Heat transfer models}

The time dependent temperature evolution in the structural element is defined by the solution of a heat transfer differential equation. The equations for the calculation of temperature increase over time in the protected and unprotected steel element were defined according to the research carried out by Wickstrom $[8,9]$. As a result of that research the equations which describe the temperature increase in the protected and unprotected steel elements which also represent a 1D differential equation of heat transfer were incorporated into Eurocode 3. Furthermore, the concept of the "shadow" factor incorporated into the calculation procedure for the first time. Shadow factor is used to reduce the heat flux due to the radiation on the element because of the specific shape of its cross-section serving as an obstacle for the radiative heat flux, a reduction observable only in elements with I type cross-section.

\section{Analysis of simple heat transfer calculation models}

This section presents the conducted experimental researches [10] which include monitoring of the temperature increase in protected and unprotected steel elements. The results of experimental research will be compared with the simple heat transfer models for protected and unprotected steel elements given in Eurocode 3 together with the predictions of a $2 \mathrm{D}$ numerical heat transfer model TASEF (Temperature Analysis of Structures Exposed to Fire).

\subsection{Experimental programme}

The experimental programme for analysing and monitoring the temperature increase in steel elements was carried 
out for unprotected elements and for elements protected by an intumescent coating. $3.0 \mathrm{~m}$ long elements were heated by automatically regulated oil burners used for simulating preferred temperature conditions in two furnaces with dimensions $3150 \times 300 \times 1000 \mathrm{~mm}$ (6 burners) and $1250 \times 700 \times 500 \mathrm{~mm}$ (1 burner). The experiment also included the monitoring of the temperature increase in elements with slow heating gradients in a furnace (element heated with a nonlinear temperature gradient). The elements heated by a nonlinear temperature curve, after reaching the desired temperature, were subjected to a constant load increase in order to obtain mechanical response of the element exposed to high temperatures. Experimental programme included the testing of steel elements I 212/180 that were exposed to bending load and combined bending and axial compression load. This paper presents only the results of the temperature measurements from the elements that were exposed to bending load, combined bending and axial compression load ${ }^{* *}$.

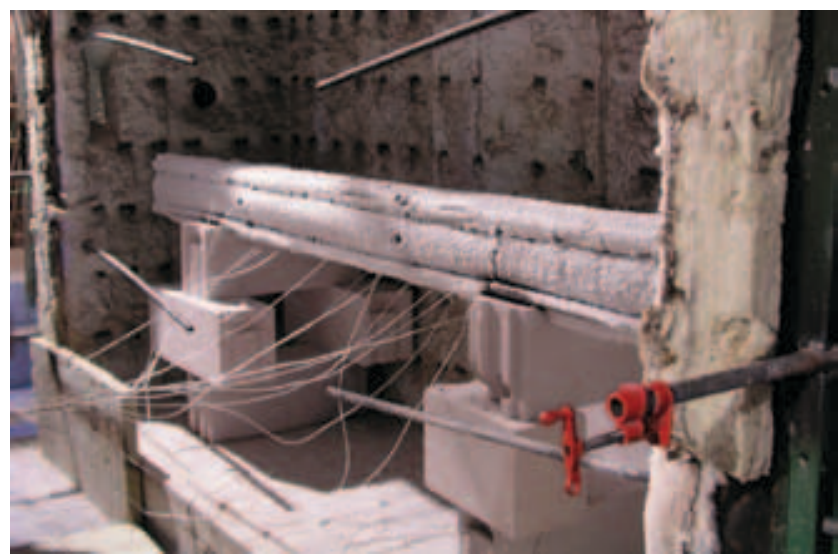

Figure 1. Steel element* inside the furnace with dimensions $3150 \times 3000 \times 1000 \mathrm{~mm}$

Three different types of steel profiles were used in the experiment (Figure 1), which cover the values of the section factor within the range from 100-300: IPE140 and IPE180 with the protection in the form of intumescent coating and the unprotected welded I 212/180 profile. Table 1 presents the list of the elements related to the measurement of temperatures on the surface of steel elements.

Heating gradient in the furnace was predefined and the temperature inside the furnace was automatically regulated for each zone of the furnace during the experiment. Temperature control in each of the furnace zone was maintained by thermocouples. Thermocouples for measurement of surface temperature of the element were welded to the discrete point on the element (Figure 2).

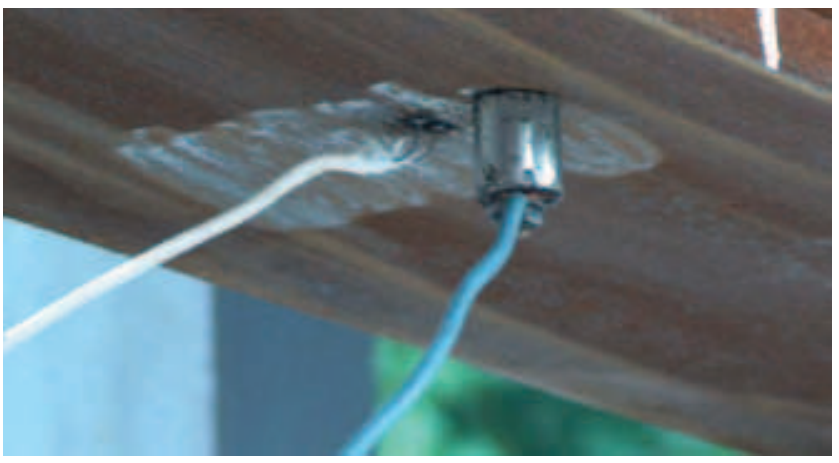

Figure 2 . Thermocouple attached to the measuring point on the element

Thermo-elements of $\mathrm{K}$ type ( $\mathrm{NiCr}-\mathrm{Ni}$ ) were used for measuring temperatures in discrete points on the element's surface. Figure 3 presents the position of measurement points at the surface of hot rolled profiles and a welded I 212/180 profile.

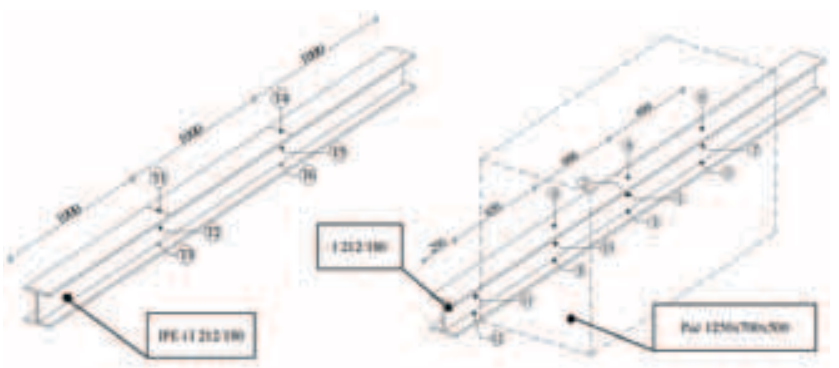

Figure 3. The position of temperature measurement points on IPE profiles and a welded profile I 212/180

The elements exposed to ISO standard fire curve were placed in entirety inside the furnace of dimension 3150×3000×1000 $\mathrm{mm}$. The elements heated by nonlinear temperature gradients were for technical reasons placed only partially within the furnace $(1250 \times 700 \times 500 \mathrm{~mm})$ to prevent a possible damage of the equipment for monitoring the element deflection after the heating and loading cycles (Figure 3).

Table 1. List of elements used for measurement of the surface temperatures

\begin{tabular}{|c|c|c|c|c|c|}
\hline Element type & Heating regime & Protection type & $\begin{array}{c}\text { Furnace dimensions } \\
{[\mathrm{mm}]}\end{array}$ & $\begin{array}{c}\text { Max. heating } \\
\text { temp. }\left[{ }^{\circ} \mathrm{C}\right]\end{array}$ & Total number \\
\hline IPE 140 & ISO fire & Protected & $3150 \times 3000 \times 1000$ & 800 & 1 \\
\hline IPE 180 & ISO fire & Protected & $3150 \times 3000 \times 1000$ & 800 & 1 \\
\hline I $212 / 180^{*}$ & ISO fire & Unprotected & $3150 \times 3000 \times 1000$ & 800 & 1 \\
\hline I $212 / 180^{* *}$ & Nonlinear curve & Unprotected & $1250 \times 700 \times 500$ & $400-700$ & 7 \\
\hline
\end{tabular}




\subsection{Modelling of heat transfer according to EN1993-1-2}

\subsubsection{Basic model assumptions}

Simple calculation models for heat transfer according to EN 1993-1-2 are based on the following assumptions:

- Temperature is uniformly distributed over the surface of the cross-section of element (1D heat transfer model),

- Temperature increase in the element is directly proportional to section factor of the cross-section,

- Temperature of the surrounding gas is equal to the temperature of the surface of the fire-insulation material in case of elements protected with fire insulation material.

\subsubsection{Calculation model}

Equations for the calculation of temperature increase in time for protected and unprotected elements according to EN 1993-1-2 are given by expressions 1 and 2:

$$
\begin{aligned}
\Delta \theta_{a, t} & =k_{s h} \cdot \frac{A_{m} / V}{c_{a} \cdot \rho_{a}} \cdot \dot{h}_{n e t, d} \cdot \Delta t \\
\Delta \theta_{a, t} & =\frac{\lambda_{p} \times A_{p} / V}{d_{p} \times c_{a} \times \rho_{a}} \times \frac{\left(\theta_{g, t}-\theta_{a, t}\right)}{(1+\phi / 3)} \times \Delta t-\left(e^{f / 10}-1\right) \times \Delta \theta_{g, t} \\
\phi & =\frac{c_{p} \times \rho_{p}}{c_{a} \times \rho_{a}} \times d_{p} \times A_{p} / V
\end{aligned}
$$

where:

$\Delta \theta_{a, t}$ - temperature increase in the element at time interval $\Delta \mathrm{t}\left({ }^{\circ} \mathrm{C}\right)$

$k_{\text {sh }} \quad$ - shadow factor

$A_{m} / V$ - ection factor $\left(\mathrm{m}^{-1}\right)$

$A_{m} \quad$ - the surface area of the element per unit length $\left(\mathrm{m}^{2}\right)$

$V \quad$ - the volume of the element per unit length $\left(\mathrm{m}^{3}\right)$

$C_{a^{\prime}} \rho_{a}-$ specific heat capacity $(\mathrm{J} / \mathrm{kgK})$ and density of steel $\left(\mathrm{kg} / \mathrm{m}^{3}\right)$

$C_{p^{\prime}} \rho_{p}$ - specific heat capacity $(\mathrm{J} / \mathrm{kgK})$ and density of fire insulation material $\left(\mathrm{kg} / \mathrm{m}^{3}\right)$

$\dot{h}_{n e t, d}$ - convective and radiative heat flux $\left(\mathrm{W} / \mathrm{m}^{2}\right)$

$\Delta t \quad$ - time interval (s)

$\lambda_{p^{\prime}} d_{p}$-thermal conductivity of fire insulation material (W/ $\mathrm{mK}$ ) and thickness of fire insulation material (m)

$A_{p} / V$ - the section factor for protected sections $\left(\mathrm{m}^{-1}\right)$

$\theta_{g, t} \quad$ - temperature at the surface of fire insulation material $\left({ }^{\circ} \mathrm{C}\right)$

$\theta_{a, t} \quad$ - temperature of the steel element from previous time interval $\left({ }^{\circ} \mathrm{C}\right)$.
Shadow factor $k_{s h}$ is generally determined from:

$k_{s h}=\frac{A_{m, b}}{A_{m}}$

Illustration of the surfaces $A_{m, b}$ i $A_{m}$ in case of I-shape elements is shown on Figure 4.

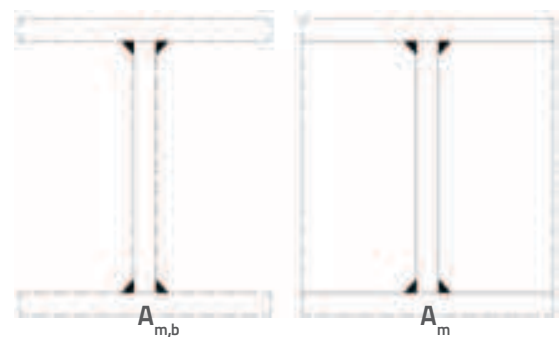

Figure 4. Definition of shadow factor

Expression for the calculation of the heat flux $h_{\text {net, }}$ according to EN1991-1-2 [11] is given by the following equation:

$\dot{h}_{n e t, d}=\alpha_{c} \cdot\left(\theta_{g}-\theta_{m}\right)+\Phi \cdot \varepsilon_{r e s} \cdot \sigma \cdot\left(\theta_{g}^{4}-\theta_{m}^{4}\right)$

where:

$\alpha_{c} \quad-$ convection coefficient $\left(\mathrm{W} / \mathrm{m}^{2} \mathrm{~K}\right)$

$\Phi$ - configuration factor

$\varepsilon_{\text {res }} \quad$ - the resulting factor of emissivity between the steel element and fire

$\sigma \quad$ - the Stephan-Boltzmann constant $\left(=5,67 \mathrm{~A} 10^{-8} \mathrm{~W} /\right.$ $\left.\mathrm{m}^{2} \mathrm{~K}^{4}\right)$

$\theta_{g} \mathrm{i} \theta_{m}$-gas temperature around the element and the temperature of the element surface $\left({ }^{\circ} \mathrm{C}\right)$.

The temperature of the gas surrounding the element $\theta_{g}$ for heat transfer modelling by expressions 1 and 2 was taken as a mean value of the furnace temperature. It is important to note that the expression for heat transfer modelling in protected elements according to EN 1993-1-2 (equation 2) is proposed only for cases of fire insulation material with constant thickness $d_{p}$.

\subsubsection{Heat transfer modelling parameters for unprotected steel elements}

Table 2 presents the values of parameters used for the calculation of the developed temperatures in protected and unprotected elements.

Table 2. Basic input data for modelling of heat transfer according to EN1993-1-2

\begin{tabular}{|c|c|c|c|c|c|c|c|c|}
\hline Parameters & $C_{a}$ & $\rho_{\mathrm{a}}\left[\mathrm{kg} / \mathrm{m}^{3}\right]$ & A/V $\left[\mathrm{m}^{-1}\right]$ & $k_{s h}$ & $\alpha_{\mathrm{c}}\left[\mathrm{W} / \mathrm{m}^{2} \mathrm{~K}\right]$ & $\boldsymbol{\Phi}$ & $\boldsymbol{\varepsilon}_{\mathrm{res}}$ & $\Delta \mathrm{t}[\mathrm{s}]$ \\
\hline Protected & EN1993-1-2 & 7850,0 & $291 / 335$ & 1,0 & 25,0 & 1,0 & 0,7 & 3,0 \\
\hline Unprotected & EN1993-1-2 & 7850,0 & 129 & 0,65 & 25,0 & 1,0 & 0,7 & 3,0 \\
\hline
\end{tabular}




\subsubsection{Heat transfer modelling parameters for protected steel elements}

The analysed protected elements were coated with an intumescent coating based on an artificial resin which when heated at the temperature of coating expansion $T_{\text {exp }}$ changes to foam and suddenly increases its volume - up to 50 times. The volume increase leads to a density decrease of the resulting foam which can be reduced up to 100 times [12]. The consequence of the two presented phenomena, i.e. the changeable thickness of the coating-foam occurs in dependence on the temperature. This chapter presents several types of growth models of the developed thickness of the protective layer of fire insulation material in order to decide which growth model best describes the temperature rise in the protected steel element. The basic parameters used for modelling the development of protective foam layer and its influence upon the reduced heating of elements are given in Table 3.

Table 3. Basic parameters for heat transfer modelling in elements with intumescent coating as protection

\begin{tabular}{|c|c|c|c|c|c|}
\hline $\begin{array}{c}\mathrm{T}_{\exp } \\
{\left[{ }^{\circ} \mathrm{C}\right]}\end{array}$ & $\begin{array}{c}\mathrm{C}_{\mathrm{p}} \\
{[\mathrm{J} / \mathrm{kgK}]}\end{array}$ & $\begin{array}{c}\lambda_{\mathrm{p}} \\
{[\mathrm{W} / \mathrm{mK}]}\end{array}$ & $\begin{array}{c}\mathrm{d}_{\mathrm{p}, \max } \\
{[\mathrm{cm}]}\end{array}$ & $\begin{array}{c}\boldsymbol{\rho}_{\mathrm{p}} \\
{\left[\mathrm{kg} / \mathrm{m}^{3}\right]}\end{array}$ & $\begin{array}{c}\boldsymbol{\rho}_{\text {coating }} \\
{\left[\mathrm{kg} / \mathrm{m}^{3}\right]}\end{array}$ \\
\hline 300 & 1000 & $0,25-0,5$ & 4 & 20 & 1200 \\
\hline
\end{tabular}

The final foam thickness $d_{p, \text { max }}$ was determined experimentally after the end of the heating cycle. The values of the thermal conductivity $\lambda_{p}$ and a specific heat capacity $c_{p}$ were taken from literature [13]. The model of the increased thickness of the protective layer was given for two cases; model 2 - linear increase in thickness to the final value $d_{p, \max }$ until the end of high temperature exposure (the thickness starts increasing linearly after reaching the fire temperature of $300^{\circ} \mathrm{C}$ ) and a model 3 - sudden increase of thickness of the protective layer up to a final value $d_{p, \max }$ immediately after reaching the temperature of $300^{\circ} \mathrm{C}$. In addition, the temperature increase in the protected element is also analysed for the case when the thickness of the protective layer is taken as a constant over the entire temperature range - model 1 (alternative thickness of the protective layer $d_{p, e f f}$.

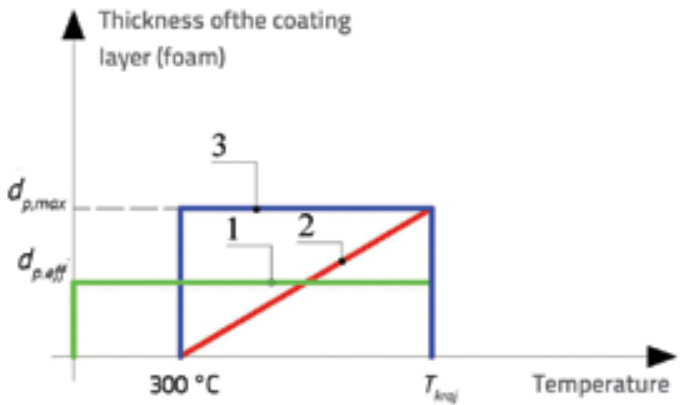

Figure 5. Employed models of the thickness increase of a protective layer of the intumescent coating

\subsubsection{Heat transfer modelling parameters - TASEF}

Values of basic parameters for 2D model TASEF that were used for calculating increase of temperatures are presented in Table 4. TASEF does not support the input of shadow factor in the explicit form into the calculation procedure. Consequently, the results are obtained without taking the shadow factor into consideration.

Table 4. Basic parameters for heat transfer modelling in TASEF

\begin{tabular}{|c|c|c|c|c|c|}
\hline Parameters & $\mathbf{C}_{\mathrm{a}}$ and $\lambda_{\mathrm{a}}$ & $\begin{array}{c}\boldsymbol{\rho}_{\mathrm{a}} \\
{\left[\mathrm{kg} / \mathrm{m}^{3}\right]}\end{array}$ & $\Phi$ & $\boldsymbol{\varepsilon}_{\text {res }}$ & $\begin{array}{c}\Delta \mathbf{t} \\
{[\mathbf{s}]}\end{array}$ \\
\hline Protected & EN1993-1-2 & 7850,0 & 1,0 & 0,7 & 1,0 \\
\hline Unprotected & EN1993-1-2 & 7850,0 & 1,0 & 0,7 & 1,0 \\
\hline
\end{tabular}

\subsection{Results - protected steel elements}

Figures 6 and 7 present the diagrams of the developed temperature in single points on the surface of the IPE 140 and IPE 180 profiles and the comparison with the results of the heat transfer model for protected elements from EN1993-1-2. They present the temperature increase when the $k_{p}=\lambda_{p} \times d_{p} \times c_{p}$ parameter is equal to 10 and 20 which corresponds to the case when the protective layer is taken as a constant (Model 1) over the entire temperature range with a thickness of 2 and $4 \mathrm{~cm}$, respectively. The heat transfer calculation is given according to Model 2 for two cases: for the coefficient of thermal conductivity $\lambda_{p} 0,25$ and $0,5 \mathrm{~W} / \mathrm{mK}$. The calculation is also given according to Model 3 for the same values of the thermal conductivity coefficient. The Figure also presents the temperatures obtained by modelling the cross-section of an element in a $2 \mathrm{D}$ transient nonlinear heat transfer model TASEF [14] where the input parameters were coefficients of thermal conductivity and the specific heat capacity from EN1993-1-2 (Table 4).

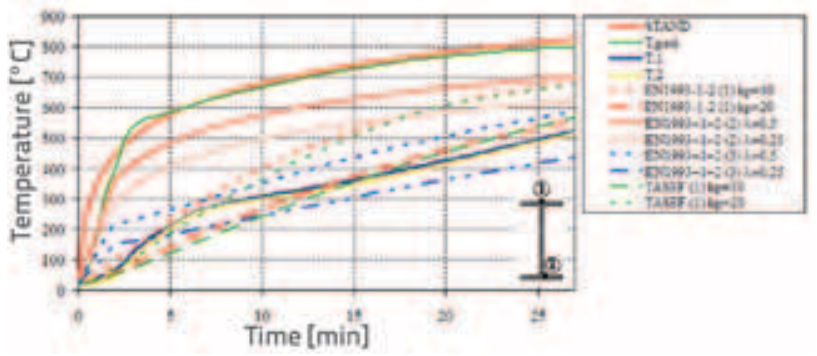

Figure 6. The results of developed temperatures in IPE140 profile and comparison with EN1993-1-2 and TASEF

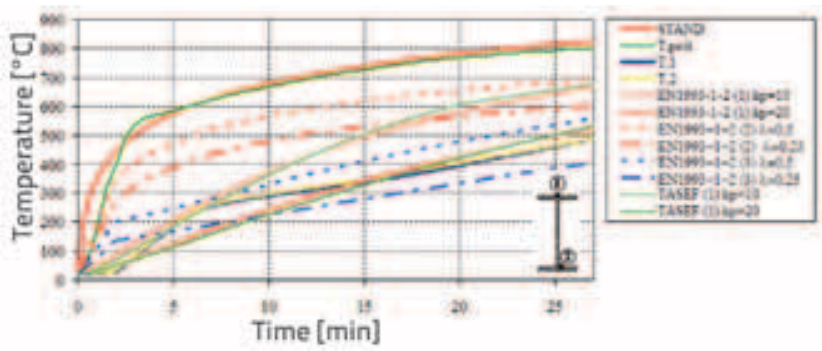

Figure 7. The results of the developed temperatures in IPE180 profile and comparison with the EN1993-1-2 and TASEF 


\subsection{Results - unprotected steel elements}

Figure 8 presents the diagrams of the developed temperatures at specified points of the unprotected welded I $212 / 180$ profile and the comparison with the temperature obtained by the heat transfer model for unprotected elements from EN19931-2. Two curves were computed according to the EN 1993-1-2 model, with and without including the shadow factor $k_{s h}$.

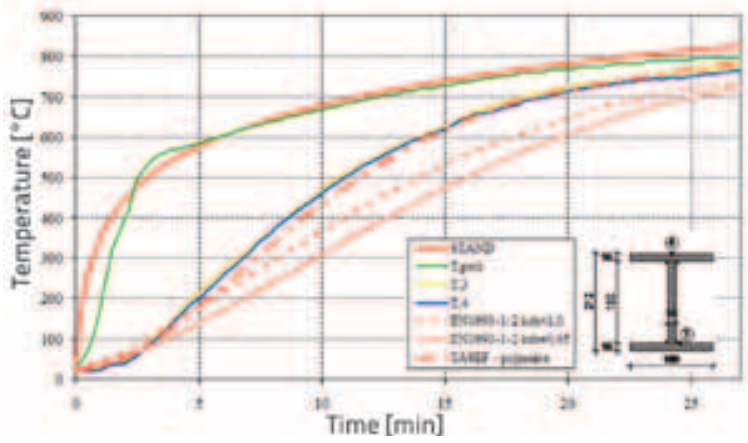

Figure 8 . The results of the developed temperatures in I 212/180 profile and comparison with EN1993-1-2 and TASEF

Figures $9-12$ present the measured temperatures at characteristic points of element for the nonlinear increase of temperature in the furnace for $400-700^{\circ} \mathrm{C}$ temperature levels (bending test). Comparison is given between the results of the experiment and the results of the heat transfer model from EN1993-1-2 and TASEF. Two curves were computed according to the EN 1993-1-2 model, with and without including the shadow factor $k_{s h}$.

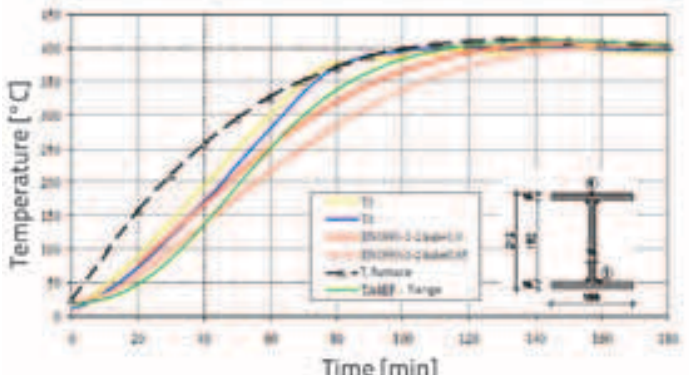

Figure 9. The comparison of results in case of nonlinear heating of element, $400^{\circ} \mathrm{C}$ (bending test)

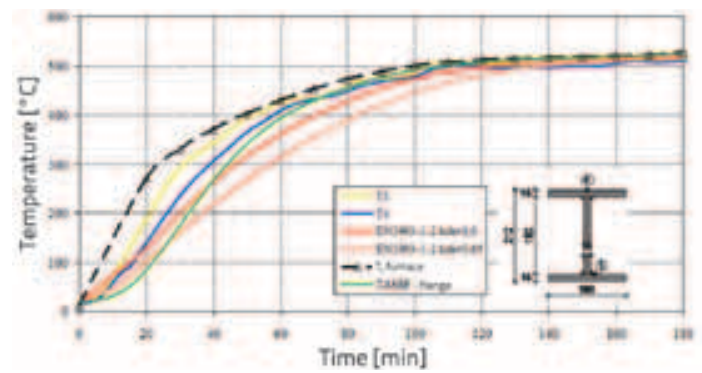

Figure 10. The comparison of results in case of nonlinear heating of element, $500^{\circ} \mathrm{C}$ (bending test)

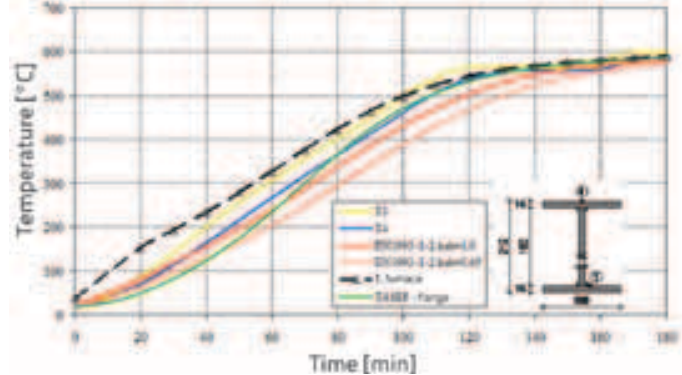

Figure 11. The comparison of results in case of nonlinear heating of element, $600^{\circ} \mathrm{C}$ (bending test)

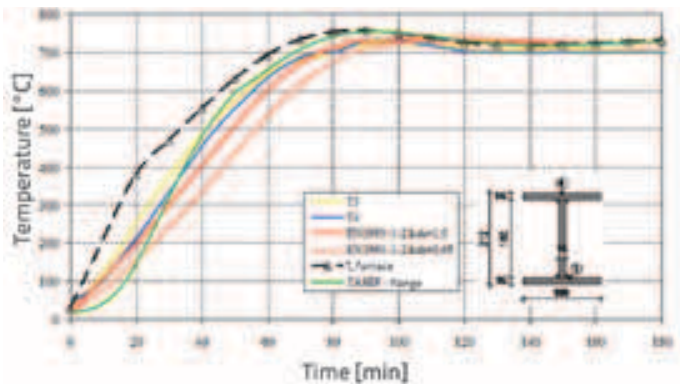

Figure 12. The comparison of results in case of nonlinear heating of element, $700^{\circ} \mathrm{C}$ (bending test)

Figures 13, 14 and 15 present the measured temperatures at characteristic points of element for the nonlinear increase of temperature in the furnace for $400-600^{\circ} \mathrm{C}$ temperature levels (combined bending and axial compression test).

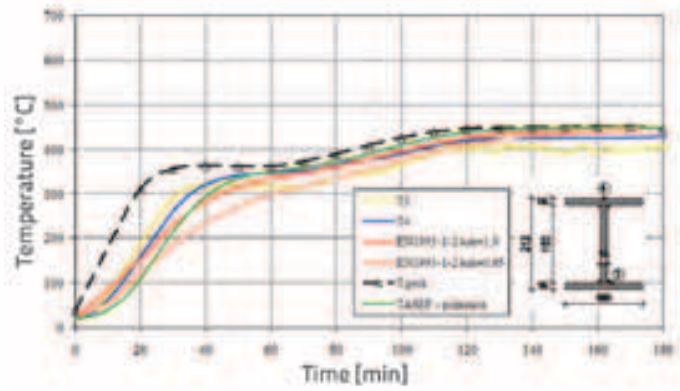

Figure 13. The comparison of results in case of nonlinear heating of element, $400^{\circ} \mathrm{C}$ (combined bending and axial compression test)

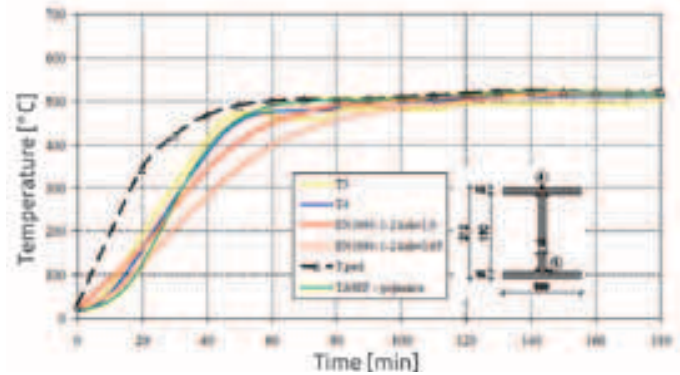

Figure 14. The comparison of results in case of nonlinear heating of element, $500^{\circ} \mathrm{C}$ (combined bending and axial compression test) 


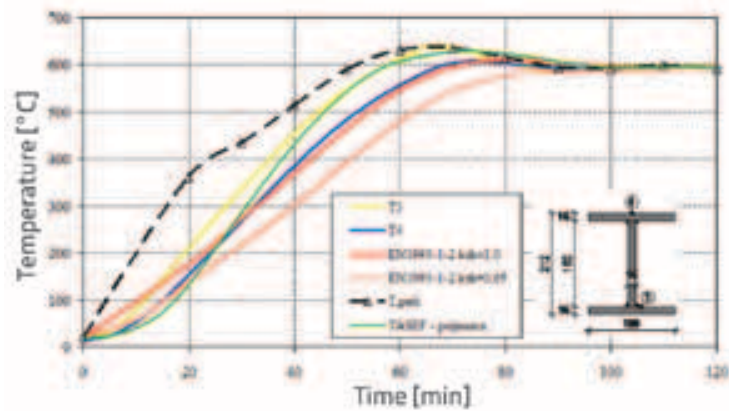

Figure 15. The comparison of results in case of nonlinear heating of element, $600^{\circ} \mathrm{C}$ (combined bending and axial compression test)

\subsection{Analysis of results}

The results of heating the unprotected elements show that the EN1993-1-2 model does not describe accurately the temperature increase in the element during the time interval of 25 minutes for the case of element heating by a standard fire curve, especially if the shadow factor is included into heat transfer analysis (Figure 8). From the analysis of the trend of temperature increase according to EN 1993-1-2 and the temperature increase in an unprotected element it is evident that in time interval after 25 minutes the temperatures obtained by the EN 1993-1-2 model approach the temperatures measured in the steel element. The comparison of results from Figures 9-15 show that, for the case of the nonlinear heating of elements, heat transfer model proposed by Eurocode 3 predicts with sufficient precision the temperatures in heated steel elements, with maximum discrepancy of $50^{\circ} \mathrm{C}$ between the measured and predicted temperature.

The results obtained by the computer programme TASEF suggest that the models of the coefficient of thermal conductivity and specific heat capacity from EN19931-2 describe with a satisfactory precision temperature development in welded element, which is in accordance with the conclusions given in chapter 2.1. This result justifies the use of parameters of temperature dependent thermal characteristics proposed by EN1993-1-2 for heat transfer modelling of the tested elements.

The results of testing the protected steel elements coated with an intumescent coating (Figures 6 and 7) show that Model 3 of the thickness increase of the protective layer describes best the temperature increase in a protected element, which represents an actual phenomenon accompanied by a sudden chemical reaction. The reaction results in an instantaneous increase of the thickness of intumescent coating (foam). It is also evident that modelling by use of effective protective layer within the entire temperature range (Model 1) yields satisfactory results for the prediction of temperature increase. The agreement between Models 1 and 3 for the thickness increase of the protective layer with experimental results is obtained by using the coefficient of thermal conductivity of intumescent coating in the range between 0,25 and 0,5 W/ $\mathrm{mK}$, which represents a realistic value of the coefficient of thermal conductivity of intumescent coating at temperatures higher than $350^{\circ} \mathrm{C}$ [13]. There is a significant discrepancy in the first five minutes between the EN 1993-1-2 model and the experiment, however, in the later stages temperature increase gradient given by model EN1993-1-2 corresponds the experimentally determined values of the measured temperatures. Temperatures developed in the upper and lower flange of the heated elements show that in the case of heating with ISO fire curve temperature is almost identical over the height of the cross-section for the entire element length (uniform temperature per element), while in the case of nonlinear element heating the distribution of temperatures is slightly nonlinear within the element with a maximum difference of $50^{\circ} \mathrm{C}$ in temperatures between the upper and lower flange. It can be concluded that the temperature distribution in the tested elements was approximately uniform which is in accordance with the basic model assumption from chapter 3.2.1.

\section{Discussion of the results}

The analysis of the results of developed temperatures obtained by simple heat transfer models according to Eurocode 3 shows that the heat transfer model for unprotected steel elements predicts temperature development in element with sufficient precision for low temperature gradients inside the furnace compared to the case of higher temperature gradients (ISO fire curve). Higher discrepancy between the results is observed if shadow factor, which reduces the total heat flux resulting from convection and radiation, is taken into account. However, shadow factor should be used to reduce only the convective part of heat flux since, in reality, there is no obstacle to convective heat flux due to specific I shape of the element. Nonetheless, simple heat transfer models from EN 1993-1-2 use shadow factor to reduce both the convective and radiative part of heat flux.

It is important to note that the developed temperatures in the element at higher temperature gradients inside the furnace gradually correspond to those obtained by Eurocode 3 model, meaning that, if the element is exposed to maximum temperatures long enough, eventually the same predictions of the temperature development will be obtained as those obtained by Eurocode 3 model. However, the disagreement between the results in the initial phase of fire development, when the temperature has the highest increase, leads to a possibly imprecise determination of a structure's load bearing capacity in case of fire. Only in case where longer fire resistance time of a structure is required, i. e. when fire has fully developed, temperature values reach agreement and the estimation of a structure's load bearing capacity becomes more precise. 
The calculation of heat transfer in the elements protected by an intumescent coating according to Eurocode 3 model gives good results if the critical set of parameters, which has to be determined in order to ensure sufficiently accurate predictions of the developed temperatures, is determined before the beginning of calculation. The critical set of parameters which should be determined before the calculation are: maximal thickness of the fire resistant foam, temperature of coating expansion, foam density, the averaged specific heat capacity and the thermal conductivity coefficient of the coating in temperature interval $300-500^{\circ} \mathrm{C}$. All of the mentioned parameters need to be given by the manufacturer of intumescent coating in accordance with EN 1993-1-2 norm in order to enable the calculation of heat transfer in elements protected by the coating.

\section{Conclusions}

Considering the performed experimental and theoretical study related to modelling of heat transfer in structures several conclusions and recommendations can be reached. It is possible to model temperature increase in steel elements protected with intumescent coating by using simple calculation models for heat transfer according to EN 1993-1-2. Modelling of heat transfer in elements protected with intumescent coating according to EN 1993-1-2 gives good results if using the proposed methodology. The inclusion of shadow factor into calculation of temperature increase according to EN 1993-1-2 gives results which are not on the safe side due to an unrealistic reduction of the convective part of the heat flux. The heat transfer model for unprotected and protected steel elements given in Eurocode 3 in cases of higher temperature gradient inside furnace shows more significant deviations in the prediction of developed temperatures inside the element compared with the results obtained by the performed experiments. Therefore, the use of these models is not suitable for the analysis of heat transfer in structures exposed to fire.

\section{Acknowledgement}

The research described in this paper was carried out within scientific projects No. 083-1465 "Reliability of structures and risk assessment to extreme loading" and No. 083-00000001538 "Experimental and numerical research of earthquake resistance of structures" supported by the Ministry of Science, Education and Sport of the Republic of Croatia.

\section{REFERENCES}

[1] EN 1993-1-2:2005, Eurocode 3 - Design of steel structures - Part 1-2: General Rules Structural Fire Design, European Committee for Standardization, Brussels, 2005.

[2] Boko, I., Peroš, B.: Sigurnost nosivih čeličnih konstrukcija pri djelovanju požara, Građevinar 54, (2002.), 11, 643-656.

[3] Anderberg, Y.: Properties of Materials at High Temperatures Steel, RILEM Report, University of Lund, Sweden, 1983.

[4] ECCS Technical Committee 3, European Recommendations for the Fire Safety of Steel Structures, Calculation of the Fire Resistance of Load Bearing Elements and Structural Assemblies Exposed to the Standard Fire, Amsterdam, Elsevier Scientific Publishing company, 1983.

[5] ECCS Technical Commmittee 3, Fire Resistance of Steel Structures, ECCS Publication No. 89, Brussels: European Convention for Constructional Steelwork, 1995.

[6] Outinen, J., Kesti, J., Mäkeläinen, P.: Fire Design model for Structural Steel S355 Based Upon Transient State Tensile Test Results, Journal of Constructional Steel Research 42, (1997), 3, 161-169.

[7] Rempe, J. L., Knudson, D. L.: High Temperature Thermal Properties for Metals used in LWR Wessels, Journal of Nuclear Materials 372, (2008), 2-3, 350-357.

[8] Wickström, U.: Calculation of Heat Transfer to Structures Exposed to Fire - Shadow effects, Ninth Interflam conf., Interscience Ltd, 451-460, 2001.

[9] Wickström, U.: Temperature Analysis of Heavily-insulated Steel Structures Exposed to Fire, Fire Safety Journal 5, (1985), 281285.

[10] Boko I.: Određivanje stupnja sigurnosti nosivih čeličnih konstrukcija izloženih djelovanju požara, doktorska disertacija, Građevinsko-arhitektonski fakultet Split, 2005

[11] EN 1991-1-2:2002, Eurocode 1 - Actions on Structures - Part 1-2: General Actions - Actions on structures exposed to fire, European Committee for Standardization, Brussels, 2002.

[12] Hamins, A.: Evaluation of Intumescent Body Panel Coatings in Simulated Post Accident Vehicle Fires, NISTIR 6157, National Institute of Standards and Tehnology, Building and Fire Research laboratory, 1998.

[13] Mesquita, L.M.R.: Piloto P.A.G., Vaz, M.A.P., An Experimental Study of Intumescent Fire Protection Coatings, Second European Coatings Conference Fire Retardant Coatings. Berlin, Germany, 2007.

[14] Sterner, E., Wickstrőm U.: TASEF - Temperature Analysis of Structures Exposed to Fire, Swedish National Testing Institute, 1990. 